Diabetologia 11, 129-133 (1975)

(c) by Springer-Verlag 1975

\title{
The Effect of Phenformin upon the Plasma Pancreatic and Gut Glucagon-Like Immunoreactivity in Diabetics*
}

\author{
A. Czyżyk, L. G. Heding ${ }^{x}$, B. Malczewski and E. Miedzinska \\ Department III of Internal Diseases, Medical Academy, Warsaw, Poland and ${ }^{x}$ Novo Research Institute, Bagsvaerd, Denmark
}

Received: August 15, 1974, and in revised form: December 20, 1974

Summary. Five patients with mild maturity-onset diabetes were given $250 \mathrm{ml}$ of a $20 \%$ glucose solution by intraduodenal infusion and eight other patients similarly received an amino acid solution in a dose of $0.5 \mathrm{~g}$ amino acids per $\mathrm{kg}$ body weight. The pancreatic and gut glucagon-like immunoreactivity (pancreatic GLI and gut GLI). in plasma were measured before and after the application of the two stimuli. Each person was tested twice; the first (control) test was followed by a second test after three days of treatment with phenformin $150 \mathrm{mg}$ daily, plus the same $150 \mathrm{mg}$ dose taken $60 \mathrm{~min}$ before the intubation. The plasma pancreatic GLI increased slightly during both infusions, but was not affected by phenformin. Intraduodenal infusion of both glucose and the amino acid solution induced a greater rise in plasma gut GLI. After treatment with phenformin, the fasting plasma gut GLI was higher than the control value in eleven of thirteen patients. In most cases higher gut GLI plasma levels were also found after duodenal administration of glucose and amino acids. These data furnish further evidence of the local action of antidiabetic biguanides on the intestinal wall, including its hormonal activity. The hypothesis is advanced that the phenformin-induced increase in gut GLI secretion may bring about competition of the latter with pancreatic glucagon for receptors in liver cell membranes, reducing the effect of glucagon on the liver, and thus contributing to a decrease in glycaemia.

Key words: Diabetes, antidiabetic biguanides, blood glucose, plasma pancreatic GLI, plasma gut GLI, intraduodenal glucose administration, intraduodenal amino acid administration.
It is characteristic of the antidiabetic biguanide derivatives that they lower glycemia in diabetics in the presence of unchanged or even depressed blood insulin levels [1]. This phenomenon could be due to the inhibition by these drugs of the intestinal absorption of glucose [2-5], to the inhibition of gluconeogenesis [6], or to the potentiation of the peripheral action of insulin, modifying the kinetics or some other properties of this hormone [7-8]. Alternatively it may reflect the direct action of these drugs on factors antagonistic to insulin. In this paper we present the results of studies dealing with the effect of phenformin on the behaviour of plasma pancreatic and gut glucagon levels in diabetics.

\section{Material and Methods}

13 subjects were studied, 5 men and 8 women, 44 to 66 years of age, with mild maturity-onset diabetes and moderately overweight. They were treated either by diet alone or by diet plus drugs of the sulphonylurea group. In the latter case, drug administration was discontinued seven days before the tests. Five patients were given intraduodenal infusions of $250 \mathrm{ml}$ of a $20 \%$ solution of glucose $[50 \mathrm{~g}]$ and the remaining

* Report presented at the 8th Congress of IDF in Brussels, Belgium, 1973 eight patients received intraduodenal infusions of an amino acid mixture (Polfa, Poland ${ }^{1}$ ), $0.5 \mathrm{~g}$ amino acids per $\mathrm{kg}$ body weight. Each patient was tested twice; the first load was a control test, the second load took place after 3 days' administration of phenformin in a daily dose of $150 \mathrm{mg}$, plus the total daily dose of the drug given on the fourth day, one hour before the test. Blood glucose levels were determined according to King and the pancreatic and gut glucagon-like immunoreactivity [GLI] in plasma according to Heding, using antiserum $\mathrm{K} 814$, which does not, and antiserum $\mathrm{K} 52$, which does react with crude pork gut extract $[9,10]$. The normal values for 17 fasting persons of pancreatic GLI using the antiserum K 814 ranged from 0.16 to 0.35 (mean \pm S.E.M.: $0.20 \pm$ 0.012 ) ng equiv. per $\mathrm{ml}$. The values for gut GLI using antiserum K 52 ranged from 0.13 to 0.30 (mean \pm S.E.M.: $0.21 \pm 0.012$ ) ng equiv. per $\mathrm{ml}$ for the same 17 normal persons. Since each subject served as his own control, the significance of the differences was evaluated by the one-way paired ' $t$ ' test, for a significance level $p<0.05$. This test was also used for the

\footnotetext{
1 Composition of the amino acid mixture in $\mathrm{g}$ per litre: L-arginine 2.90; L-aspartic acid 3.00; L-cystine 0.88; L-phenylalanine 3.30; DL-glutamic acid 3.20; L-histidine 3.00 ; Lisoleucine 1.80; L-leucine 7.49; L-lysine 7.22; L-methionine 1.15; L-proline 2.26; L-serine 3.39; L-threonine 1.82; L-tryptophan 0.56; L-tyrosine 0.83 ; and L-valine 4.40.
} 
evaluation of the differences from baseline value induced by the administration of glucose or amino acids.

\section{Results}

\section{Glucose Load.}

Phenformin exerted a marked effect on the pattern of glycemia. There was a drop in fasting blood glucose, and after the second intraduodenal infusion of the glucose solution the blood glucose curve showed a characteristic flattening (see Fig. 1). Plasma pancreatic GLI increased slightly after enteral infusion of the glucose solution during the control test in five patients, whereas after previous phenformin administration it was increased in only two cases (see Table 1 and Fig. 1). The plasma gut GLI was elevated following intraduodenal infusion of the glucose solution

Table 1. Effect of phenformin on the behaviour of pancreatic GLI in plasma after intraduodenal administration of glucose and amino acids in diabetics

\begin{tabular}{|c|c|c|c|c|c|c|c|c|c|c|c|c|c|c|c|c|c|c|}
\hline \multirow{3}{*}{ No } & & \multirow{3}{*}{$\begin{array}{l}\text { Age } \\
\text { (years) }\end{array}$} & \multirow{3}{*}{ Sex } & \multirow{3}{*}{$\begin{array}{l}\text { Weight } \\
\text { (expressed } \\
\text { as percen- } \\
\text { tage of } \\
\text { ideal body } \\
\text { weight) }\end{array}$} & \multicolumn{14}{|c|}{ Plasma pancreatic GLI — ng equiv. per ml } \\
\hline & & & & & \multicolumn{7}{|c|}{ Tests before phenformin } & \multicolumn{7}{|c|}{ Tests after phenformin } \\
\hline & & & & & 0 & 15 & 30 & 45 & 60 & 90 & 120 & 0 & 15 & 30 & 45 & 60 & 90 & $120 \mathrm{~min}$ \\
\hline & & & & & \multicolumn{14}{|c|}{ Intraduodenal infusion of $250 \mathrm{ml}$ of $20 \%$ glucose solution $(50 \mathrm{~g})$} \\
\hline 1. & C. R. & 63 & M & 130 & 0.10 & 0.15 & 0.15 & 0.12 & 0.10 & 0.14 & 0.13 & 0.14 & 0.13 & 0.14 & 0.12 & 0.10 & 0.09 & 0.10 \\
\hline 2. & C. G. & 56 & $\mathbf{F}$ & 136 & 0.16 & 0.18 & 0.16 & 0.17 & 0.17 & 0.15 & 0.20 & - & 0.15 & 0.18 & 0.15 & 0.16 & 0.18 & 0.20 \\
\hline 3. & S.W. & 66 & $\mathbf{M}$ & 140 & 0.15 & 0.16 & 0.16 & 0.13 & 0.12 & 0.15 & 0.12 & 0.13 & 0.12 & 0.15 & 0.13 & 0.15 & 0.14 & 0.15 \\
\hline 4. & S.Z. & 52 & $\mathbf{M}$ & 130 & 0.12 & 0.14 & 0.12 & 0.13 & 0.12 & 0.12 & 0.10 . & 0.13 & 0.13 & 0.09 & 0.13 & 0.13 & 0.12 & 0.13 \\
\hline 5. & Z.B. & 45 & $\mathrm{~F}$ & 124 & 0.16 & 0.19 & 0.22 & 0.20 & 0.18 & 0.16 & 0.20 & 0.10 & 0.17 & 0.22 & 0.22 & - & 0.18 & 0.14 \\
\hline & & & & & \multicolumn{14}{|c|}{ Intraduodenal infusion of amino acid solution $-0.5 \mathrm{~g}$ of amino acids per $\mathrm{kg}$ body weight } \\
\hline 1. & M.S. & 44 & M & 130 & 0.10 & 0.12 & 0.12 & 0.12 & - & 0.13 & 0.22 & 0.07 & 0.15 & 0.13 & 0.13 & 0.13 & 0.10 & 0.19 \\
\hline 2. ' & S. G. & 52 & $\mathrm{~F}$ & 106 & 0.13 & 0,12 & 0.11 & 0.20 & 0.10 & 0.13 & 0.11 & 0.10 & 0.14 & 0.12 & 0.13 & 0.13 & 0.13 & 0.11 \\
\hline 3. & L.M. & 52 & $\mathbf{F}$ & 129 & 0.09 & 0.14 & 0.12 & 0.13 & 0.13 & 0.15 & 0.10 & 0.13 & 0.15 & 0.15 & 0.13 & 0.13 & 0.12 & 0.10 \\
\hline 4. & M.Z. & 59 & $\mathrm{~F}$ & 112 & 0.13 & 0.10 & 0.18 & 0.13 & 0.15 & 0.15 & 0.10 & 0.10 & 0.05 & 0.10 & 0.18 & 0.15 & 0.18 & 0.15 \\
\hline 5. & S. M. & 53 & $\mathbf{M}$ & 90 & 0.14 & 0.24 & 0.19 & 0.18 & 0.17 & 0.13 & 0.13 & 0.19 & 0.18 & 0.20 & 0.17 & 0.16 & 0.16 & 0.18 \\
\hline 6. & M.J. & 63 & F & 124 & 0.17 & 0.16 & 0.19 & 0.21 & 0.18 & 0.19 & 0.19 & 0.20 & 0.20 & 0.21 & 0.17 & 0.19 & 0.17 & 0.18 \\
\hline 7. & M.K. & 46 & $\mathrm{~F}$ & 92 & 0.22 & 0.19 & 0.20 & 0.18 & 0.18 & 0.18 & 0.19 & 0.18 & 0.20 & 0.21 & 0.18 & 0.19 & 0.18 & 0.22 \\
\hline 8. & M.S. & 64 & $\mathrm{~F}$ & 98 & 0.18 & 0.15 & 0.14 & 0.14 & 0.16 & 0.15 & 0.17 & 0.12 & 0.10 & 0.20 & 0.16 & 0.17 & 0.16 & 0.18 \\
\hline
\end{tabular}

Table 2. Effect of phenformin on the behaviour of gut GLI in plasma after intraduodenal administration of glucose and amino acids in diabetics

\begin{tabular}{|c|c|c|c|c|c|c|c|c|c|c|c|c|c|c|c|c|c|c|}
\hline \multirow{3}{*}{ No } & & \multirow{3}{*}{$\begin{array}{l}\text { Age } \\
\text { (years) }\end{array}$} & \multirow{3}{*}{ Sex } & \multirow{3}{*}{$\begin{array}{l}\text { Weight } \\
\text { (expressed } \\
\text { as percen- } \\
\text { tage of } \\
\text { ideal body } \\
\text { weight) }\end{array}$} & \multicolumn{14}{|c|}{ Plasma gut GLI - ng equiv, per $\mathrm{ml}$} \\
\hline & & & & & \multicolumn{7}{|c|}{ Tests before phenformin } & \multicolumn{7}{|c|}{ Tests after phenformin } \\
\hline & & & & & 0 & 15 & 30 & 45 & 60 & 90 & 120 & 0 & 15 & 30 & 45 & 60 & 90 & $120 \mathrm{~min}$ \\
\hline & & & & & \multicolumn{14}{|c|}{ Intraduodenal infusion of $250 \mathrm{ml}$ of $20 \%$ glucose solution $(50 \mathrm{~g})$} \\
\hline 1. & C. R. & 63 & $\mathbf{M}$ & 130 & 0.14 & 0.21 & 0.19 & 0.18 & 0.16 & 0.20 & 0.18 & 0.25 & 0.27 & 0.25 & 0.22 & 0.21 & 0.16 & 0.21 \\
\hline 2. & C. G. & 56 & $\mathbf{F}$ & 136 & 0.18 & 0.26 & 0.45 & 0.39 & 0.40 & 0.33 & 0.37 & - & 0.35 & 0.62 & 0.61 & 0.61 & 0.56 & 0.52 \\
\hline 3. & S.W. & 66 & $\mathbf{M}$ & 140 & 0.16 & 0.21 & 0.19 & 0.15 & 0.12 & 0.19 & 0.11 & 0.19 & 0.24 & 0.29 & 0.24 & 0.27 & 0.26 & 0.30 \\
\hline 4. & S.Z. & 52 & $\mathbf{M}$ & 130 & 0.26 & 0.24 & 0.23 & 0.22 & 0.20 & 0.18 & 0.21 & 0.27 & 0.23 & 0.23 & 0.27 & 0.26 & 0.33 & 0.28 \\
\hline 5. & Z.B. & 45 & $\mathrm{~F}$ & 124 & 0.12 & 0.26 & 0.31 & 0.18 & 0.31 & 0.22 & 0.20 & 0.14 & 0.45 & 0.70 & 0.65 & - & 0.33 & 0.33 \\
\hline & & & & & \multicolumn{14}{|c|}{ Intraduodenal infusion of amino acid solution $-0.5 \mathrm{~g}$ of amino acids per $\mathrm{kg}$ body weight } \\
\hline 1. & M.S. & 44 & M & 130 & 0.12 & 0.17 & 0.24 & 0.28 & - & 0.20 & 0.33 & 0.13 & 0.23 & 0.13 & 0.19 & 0.15 & 0.17 & 0.14 \\
\hline 2. & S. G. & 52 & $\mathbf{F}$ & 106 & 0.16 & 0.27 & 0.17 & 0.20 & 0.16 & 0.25 & 0.19 & 0.16 & 0.29 & 0.21 & 0.19 & 0.15 & 0.20 & 0.21 \\
\hline 3. & L. M. & 52 & $\mathbf{F}$ & 129 & 0.14 & 0.32 & 0.21 & 0.25 & 0.20 & 0.22 & 0.21 & 0.35 & 0.33 & 0.30 & 0.29 & 0.27 & 0.27 & 0.20 \\
\hline 4. & M.Z. & 59 & $\mathrm{~F}$ & 112 & 0.25 & 0.25 & 0.22 & 0.25 & 0.28 & 0.30 & 0.30 & 0.25 & 0.23 & 0.30 & 0.30 & 0.28 & 0.25 & 0.27 \\
\hline 5. & S. M. & 53 & $\mathbf{M}$ & 90 & 0.08 & 0.13 & 0.13 & 0.05 & 0.05 & 0.05 & 0.09 & 0.05 & 0.10 & 0.13 & 0.10 & 0.05 & 0.14 & 0.05 \\
\hline 6. & M. J. & 63 & $\mathbf{F}$ & 124 & 0.10 & 0.09 & 0.16 & 0.12 & 0.13 & 0.12 & 0.18 & 0.36 & 0.32 & 0.30 & 0.33 & 0.33 & 0.25 & 0.34 \\
\hline 7. & M.K. & 46 & $\mathbf{F}$ & 92 & 0.21 & 0.22 & 0.29 & 0.40 & 0.29 & 0.31 & 0.32 & 0.36 & 0.36 & 0.29 & 0.35 & 0.37 & 0.23 & 0.16 \\
\hline 8. & M.S. & 64 & $\mathbf{F}$ & 98 & 0.20 & 0.19 & 0.19 & 0.20 & 0.14 & 0.22 & 0.17 & 0.18 & 0.20 & 0.30 & 0.27 & 0.23 & 0.26 & 0.26 \\
\hline
\end{tabular}


in all the patients tested to a higher degree than the level of the plasma pancreatic GLI. After phenformin, fasting plasma gut GLI showed a rise in four patients. In four cases the second glucose load caused an increase in plasma gut GLI exceeding that observed in the control test; the differences were significant at most of the sampling times (see Table 2 and Fig. 1).

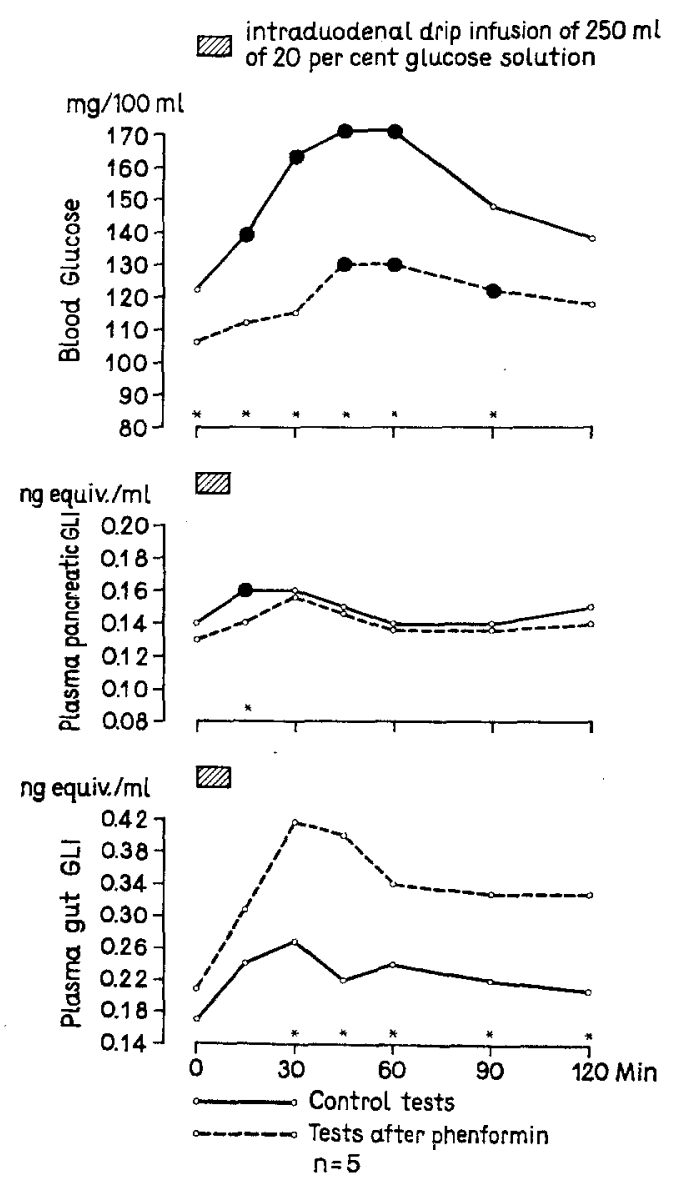

Fig. 1. The effect of phenformin upon the blood glucose level, the plasma pancreatic glucagon-like immunoreactivity (pancreatic GLI) and the plasma gut glucagon-like immunoreactivity (gut GLI) after intraduodenal glucose administration in diabetics. *Significant difference from control test - Significant difference from baseline

\section{Amino-Acid-Mixture Load}

Following intraduodenal infusion of the amino acid mixture, there was a slight decrease in the blood glucose level. In agreement with our earlier observations [11], this drop in glycemia by the end of the test was greater after prior phenformin administration (see Fig. 2). In five patients an intraduodenal load of the amino acid mixture induced a slight increase in plasma level of pancreatic GLI. Administration of phenformin affected neither the value of fasting pancreatic GLI in plasma nor its behaviour in response to intraduodenal infusion of the amino acid solution (see Table 1 and Fig. 2). On the other hand, this stimulus caused a pronounced rise in the plasma gut GLI in seven of the eight cases investigated. This increase was signi-

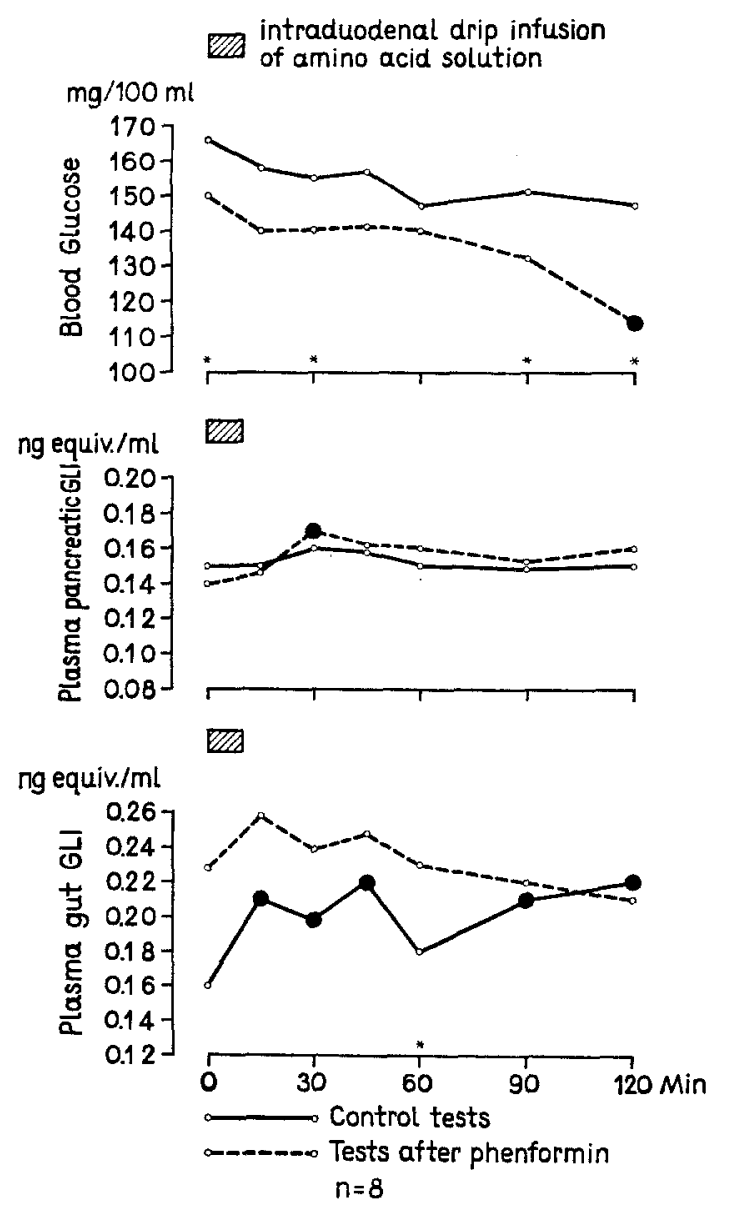

Fig. 2. The effect of phenformin upon the blood glucose level, the plasma pancreatic glucagon-like immunoreactivity (pancreatic GLI) and the plasma gut glucagon-like immunoreactivity (gut GLI) after intraduodenal amino acid administration in diabetics. * Significant difference from control test $\bullet$ Significant difference from baseline

ficant for all values obtained after amino acid administration, except at $60 \mathrm{~min}$. After phenformin, three cases exhibited a marked rise of fasting plasma gut GLI; in these patients the second amino acid load failed to further increase the gut GLI in plasma. Nevertheless, four of eight patients of this group had higher plasma gut GLI levels during the whole test after pretreatment with phenformin (see Table 2 and Fig. 2). 


\section{Discussion}

The lack of suppression of pancreatic GLI after glucose agrees with the findings published in other papers $[10,12]$. According to the present results, phenformin has no clearcut effect on the behaviour of blood pancreatic glucagon level in diabetic patients. This implies that potentiation of the action of insulin by biguanide derivatives cannot be mediated by a reduction of glucagon secretion in the pancreas. This view is supported by the investigations of Luyckx et al. [13], and those of Berger et al. [14]. The latter found that, in nondiabetic subjects, the intravenous infusion of arginine preceded by metformin caused a higher rise of pancreatic GLI in plasma than arginine alone. On the other hand, phenformin had a marked effect on the behaviour of plasma gut GLI, which cannot be considered as a factor antagonistic toward insulin. In the patients studied, the initial levels of plasma gut GLI were relatively low and in some cases they increased after phenformin administration, both on fasting and after loading with glucose and amino acids. The fact that in patients with high fasting plasma level of gut GLI, intraduodenal infusion of an amino acid solution failed to induce a response, may point to a reduction of the secretory reserve of this hormone. The experimental studies carried out recently on chickens also indicate a rise in plasma gut GLI following phenformin administration [15].

The effect of phenformin on plasma gut GLI furnishes further evidence of the importance of the action of antidiabetic biguanide derivatives on the intestinal wall, in which these drugs selectively accumulate in high concentrations [16-18]. It can be assumed that the metabolic effects of these drugs on intestinal mucosa cells are responsible for abnormal secretion and/or biosynthesis of gut glucagon-like substance.

It remains an open question whether this effect of phenformin is of any importance in the mechanism of action of the antidiabetic biguanide derivatives, since the physiological role of intestinal GLI has not so far been elucidated [cf. 19]. However, it has been shown that patients with some types of reactive hypoglycemia show an excessive gut GLI response to oral glucose, and that subsequent hypoglycemia could be prevented by exogenous glucagon [20]. It was suggested that the gut GLI competed with the pancreatic glucagon for the glucagon receptor sites in the liver thereby reducing the hyperglycemic action of glucagon. In accordance with this it has been shown that gut extracts are capable of competing with ${ }^{125}$ I-glucagon for receptor sites on isolated liver membranes [21]. The elevated gut GLI level observed after phenformin might contribute to a reduction in hyperglycemia by reducing the action of glucagon in the liver. This hypothesis assumes that changes of gut GLI in peripheral blood reflect changes of this hormone in portal blood.

\section{References}

1. Grodsky, G. M., Karam, J. H., Pavlatos, F. C., Forsham, P. H.: Reduction by phenformin of excessive insulin levels after glucose loading in obese and diabetic subjects. Metabolism 12, 278-86 (1963)

2. Czyzyk, A., Ławecki, J., Sadowski, J., Ponikowska, I., Szczepanik, Z.: Effect of biguanides on the intestinal absorption of glucose. Diabetes 17, 492-98 (1968)

3. Kruger, F. A., Altschuld, R. A., Hollobaugh, S. L.: Studies on the site and mechanism of action of phenformin. II. Phenformin inhibition of glucose transport by rat intestine. Diabetes 19, 50-52 (1970)

4. Lorch, E.: Inhibition of intestinal absorption and improvement of oral glucose tolerance by biguanides in the normal and in the streptozotocin-diabetic rat. Diabetologia 7, 195-203 (1971)

5. Caspary, W. F., Creutzfeldt, W.: Analysis of the inhibitory effect of biguanides on glucose absorption: Inhibition of active sugar transport. Diabetologia 7, 379-85 (1971)

6. Altschuld, R. A., Kruger, F. A.: Inhibition of hepatic gluconeogenesis in the guinea pig by phenformin. Ann. N. Y. Acad. Sci. 148, 612-22 (1968)

7. Creutzfeldt, W., Deuticke, U., Söling, H.-D.: Potenzierung der Wirkung von exogenem Insulin durch N-/4-Methylbenzolsulfonyl/-N'-butylcarbamid und $\mathrm{N}_{1}$-n-Butylbiguanid beim evisceriertem Tier. Klin. Wschr. 39, 790-95 (1961)

8. Butterfield, W. J. H.: Effects of biguanides on peripheral tissue. Acta diabet. lat. 6, Suppl. 1, 644- 55 (1969)

9. Heding, L. G.: Radioimmunological determination of pancreatic and gut glucagon in plasma. Diabetologia 7, 10-19 (1971)

10. Heding, L. G., Rasmussen, S. M.: Determination of pancreatic and gut glucagon-like immunoreactivity (GLI) in normal and diabetic subjects. Diabetologia 8, 408-11 (1972)

11. Czyżyk, A., Ławecki, J., Rogala, H., Malczewski, B., Kowalski, H.: The effect of phenformin on amino acid-induced insulin secretion in diabetics. Diabetologia 11, 125128 (1975)

12. Müller, W. A., Faloona, G. R., Aguilar-Parada, E., Unger, R. H.: Abnormal alpha-cell function in diabetes. Response to carbohydrate and protein ingestion. New Engl. J. Med. 283, 109-115 (1970)

13. Luyckx, A., Daubresse, J. C., Carpentier, J. L., Lefebvre, P.: La place des biguanides dans le traitement du diabète sucré. Journées de Diabétologie Hôtel-Dieu 15, 129-50 (1974)

14. Berger, W., Stahl, M., Ohnhaus, E., Goschke, H.: Pancreatic glucagon, plasma insulin and blood glucose responses to arginine infusion in nondiabetic subjects following biguanide pretreatment. Horm. Metab. Res., 6, 165 (1974)

15. Langslow, D. R., Buchanan, K. D., Freeman, B. M.: The effect of phenformin on plasma glucagon-like immunoreactivity (GLI) concentrations (abstract). Diabetologia 10, 375 (1974)

16. Cohen, Y., Costerousse, O.: Étude autoradiographique chez la souris d'un antidiabétique oral, le NN-Diméthyl- 
biguanide marqué au carbone 14. Thérapie 16, 109-20 (1961)

17. Youh, Y. J.: Distribution of $n$-buthylbiguanide-11 $\mathrm{C}$ hydrochloride in mouse tissues. Jap. J. Pharmacol. 17, 439-49 (1967)

18. Hall, H., Ramachander, G., Glassman, J. M.: Tissue distribution and excretion of phenformin in normal and diabetic animals. Ann. N. Y. Acad. Sci. 148, 601-11 (1968)

19. Moody, A. J., Heding, L. G.: Markussen, J., Steenstrup, C., Sundy, F.: The connection between gut GLI and insulin releasing activity. In: Origin, chemistry, physiology and pathophysiology of gastrointestinal hormones (Creutzfeldt W., ed.), pp. 185-98. Stuttgart-New York: K. F. Schattauer Verlag 1970
20. Rehfeld, J. F., Heding, L. G., Holst, J. J.: Increased gut glucagon release as pathogenetic factor in reactive hypoglycaemia? Lancet 1973 I, 116-18

21. Bataille, D. P., Freychet, P., Kitabgi, P. E., Rosselin, G. E.: Gut glucagon: a common receptor site with pancreatic glucagon in liver cell plasma membranes. FEBS Letters 30, 215-18 (1973)

Prof. Dr. med. A. Czyżyk

Department III of Internal

Diseases

Medical Academy Warsaw

ul. Lindleya 4

P-02-005 Warszawa

Poland 